\title{
Implementing Affirmative Action: Global Trends
}

\author{
Julie Ballington*
}

\begin{abstract}
This scoping article gives a global picture of dynamics, trends, policies and mechanisms for engaging with women's representation in political office. It discusses the kind of affirmative action introduced, and where it features vis-à-vis electoral cycles. It describes and compares candidate and reserved seats quotas and shows how electoral systems influence the possibilities of challenging power hierarchies in politics. The second part of the article reflects on the extent to which implementing quotas have been effective in engendering political representation and the conditions that allow or inhibit this.
\end{abstract}

\section{Women in parliament: averages from a global perspective}

The trend in terms of women's representation over the past decade has been one of gradual but steady progress. In 1975, at the time of the First World Conference on Women held in Mexico City, women accounted for 10.9 per cent of MPs worldwide. Ten years later, in 1985, women's representation had increased by only one percentage point, to an average of 12 per cent. In 1995, the number of women parliamentarians had actually decreased to 11.6 per cent, but a new impetus for women's participation in decision-making spheres found expression at the Fourth World Conference on Women, held in Beijing in 1995, and the adoption of the Beijing Platform for Action (BPFA). The Platform for Action highlighted special measures that States could implement to increase the participation of women in politics, including setting targets with a view to achieving equal participation of men and women (Table 1).

By 2000, the number of women in parliament had increased to 13.4 per cent in the lower houses of parliament, reaching a high in March 2010, when it peaked at 19.1 per cent. The highest rate of increase has therefore been registered during the past decade. There are several factors that account for this and they will be touched on later in this article. But the increases are not present across all countries, and there are certainly significant regional variations.

\subsection{Regional trends}

Since 1995, the Nordic countries have always had the highest representation of women. Their regional average increased to over 40 per cent after Sweden elected more women to its

Table 1 Women in parliament 1945-2010

\begin{tabular}{llllllll}
\hline & $\mathbf{1 9 4 5}$ & $\mathbf{1 9 6 5}$ & $\mathbf{1 9 7 5}$ & $\mathbf{1 9 8 5}$ & $\mathbf{1 9 9 5}$ & $\mathbf{2 0 0 0}$ & $\mathbf{2 0 1 0}^{*}$ \\
\hline Number of parliaments & 26 & 94 & 115 & 136 & 176 & 177 & 186 \\
Women representatives (lower house or unicameral) (\%) & 3.0 & 8.1 & 10.9 & 12.0 & 11.6 & 13.4 & 19.1 \\
Women representatives (upper house) (\%) & 2.2 & 9.3 & 10.5 & 12.7 & 9.4 & 10.7 & 17.9 \\
\hline
\end{tabular}

*Women in National parliaments, 31 March 2010, see www.ipu.org/wmn-e/world.htm (accessed August 2010).

IDS Bulletin Volume 41 Number 5 September 2010 (c) 2010 The Author. Journal compilation (? Institute of Development Studies Published by Blackwell Publishing Ltd, 9600 Garsington Road, Oxford OX4 2DQ, UK and 350 Main Street, Malden, MA 02148, USA 


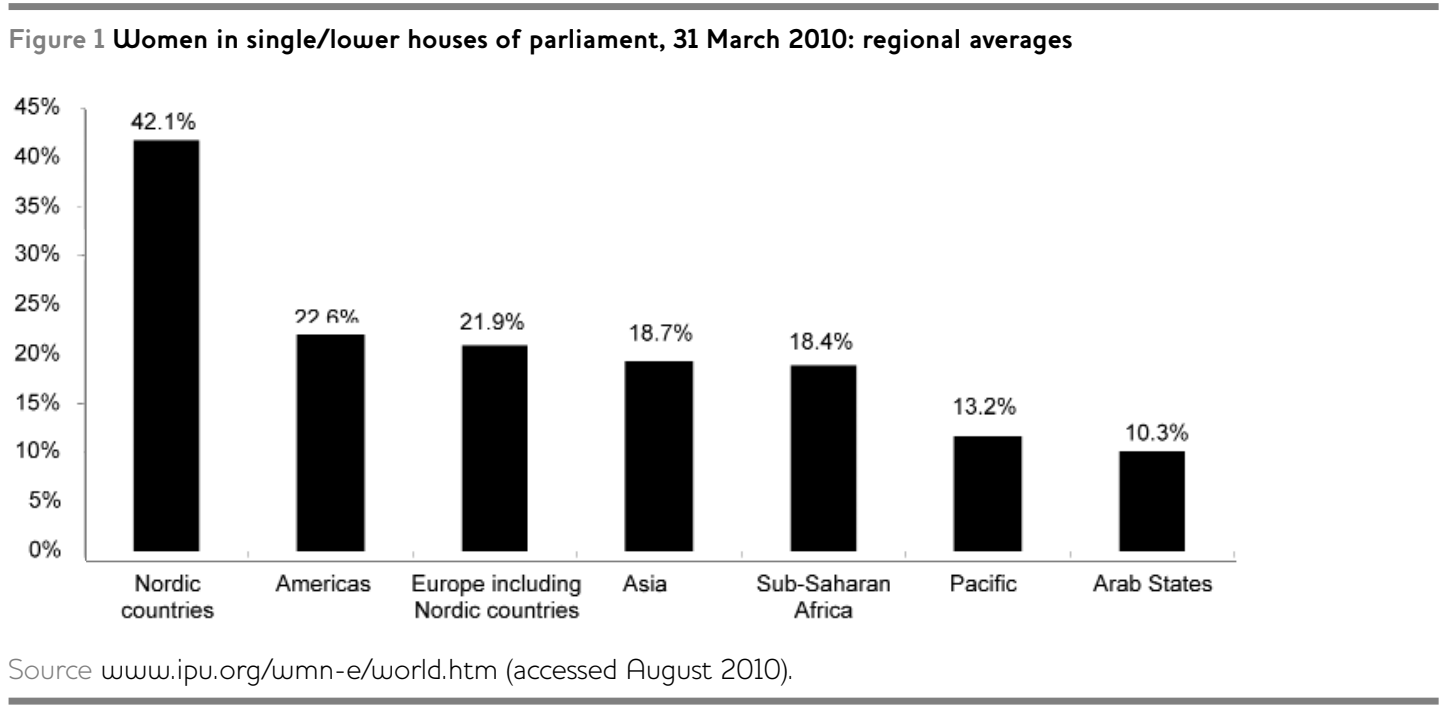

parliament than ever before in its 2006 elections, with 46 per cent women members, placing it second in the global rankings after Rwanda. During 2009, a big gain was registered in Iceland, where the Althingi elected the highest proportion of women members in its history, at 42.9 per cent, placing it fifth in the global rankings. Iceland is closely followed by Finland and Norway, with 40 per cent women members (Figure 2).

As a region, the representation of women is lowest in the Arab States at just over 10 per cent; however, there have been some notable gains recently. During 2009, women took over 27 per cent of the seats in the Tunisian election. In Kuwait's last election, four women were elected to the 50-member chamber, the first women elected in the country's history.

All the other regions fall within these contrasts, the Americas scoring second highest with 22 per cent women members, just slightly ahead of Europe, but half the average of the Nordic countries. In 2009, Bolivia elected 47 per cent women members to its upper house, and Argentina elected 38.5 per cent women members to its lower house and 34.7 per cent to its upper house, assisted by its electoral quota arrangements.

\subsection{Electoral quotas}

The incremental change over the past decades clearly demonstrates that women have faced, and continue to face, persistent challenges relating to their political participation. Given the uneven access of women to parliaments, and to compensate for the obstacles they face in the electoral process, special measures, or quotas specifically, have been implemented all over the world. Quotas provide a fast track for women to access parliament - in a short space of time. Often in one election, the number of women parliamentarians can increase dramatically.

There are two main types of quotas, depending on where the quota is located in the electoral cycle. The electoral cycle has at least two distinct phases - the first is the supply side where candidates and political parties are presented for election and voted for by the electorate (candidate quotas). The second is the output side, where the votes cast are translated into seats in parliament (reserved seats).

\section{Candidate quotas}

The first type of quota, the candidate quota, is related to the supply side. Candidate quotas require that women be nominated as candidates for election. These quotas can either be legislated, where the law specifies a minimum percentage of candidates who must be female, or they can be voluntary, where a political party adopts, on a voluntary basis, a specified target of women candidates it will put forward to contest the election. These are usually applied in proportional representation systems.

\section{Reserved seats}

The second type of quota applies to the output side of distributing seats in parliament, and usually guarantees that women hold a certain number of seats in parliament. These are 
reserved seats which can be directly elected, appointed, nominated or filled by political parties in proportion to the number of seats each party holds in parliament. Reserved seats are usually legislated in electoral or political party laws and regulations. They are usually used in plurality or majority electoral systems.

\section{Electoral systems}

There is strong evidence to suggest that the type of electoral system in place in a country can greatly affect women's chances of election. Research into the results of elections held during 2009 finds that:

- In the 24 elections that used PR in 2009, women took an average of 26 per cent of the contested seats. Quotas were also used in most of these elections to boost women's participation rates as candidates, including voluntary candidate quotas adopted by political parties and legislated quotas with enforcement mechanisms.

- In the nine chambers that used mixed electoral systems, that is, a combination of PR and majority elections, women took 24.6 per cent of the seats. In seven of these elections, quotas were applied to the seats filled using the PR system.

- In the 13 chambers elected using majority/plurality electoral systems, the proportion of women elected was just 13.2 per cent - half the average under PR systems. One of the main problems associated with majority/plurality systems is the difficulty in applying electoral quotas. ${ }^{1}$

Electoral systems alone do not determine the level of representation of women, but they are important because they can be used in conjunction with quotas to promote women's access to political power. Quotas must work together with the type of electoral system. This article deals with the two main types of electoral systems: plurality or majority systems and proportional representation systems.

\subsection{Plurality or majority electoral systems}

In plurality or majority electoral systems, usually one candidate is directly elected in a district after obtaining the highest number of votes. As a party can only win one seat in a district, it is very hard to implement a candidate quota for women. Political parties usually field only one candidate and they cannot 'balance the party ticket' by including both men and women. Female candidates must compete directly with men to win the nomination of the party, which in many instances proves a great challenge. Because of the mechanics of this system, the trend is for quotas to be implemented by reserving seats in parliament. Examples of countries implementing the reserved seats formula include Jordan, Rwanda, Tanzania and Uganda.

\subsection{Proportional representation systems}

In proportional representation systems, several candidates are elected in a district. Voters usually choose between political parties, rather than vote for individual candidates. Political parties then receive a share of seats in parliament, based on their overall share of the vote received. Most systems have 'closed' lists where the party determines the ranking of candidates on its list. In an 'open' list, voters may influence to some extent the order of candidates by noting a preference for a particular candidate and increasing the chances of that candidate being elected.

It is through the use of party lists that it becomes possible to implement a quota on the supply side, known as candidate quotas. As parties compile their lists, they can be obliged, or can choose, to ensure that a set number of the candidates for election are female.

Since the early 1990s, there has been a proliferation in the number of countries implementing candidate quotas. Every region in the world has seen countries adopting quotas and today, there are some 50 countries that have implemented candidate quotas for women by law. Legislated candidate quotas are used in 11 countries in Latin America, including Argentina, Costa Rica, Chile and Brazil. They are used in European countries, including Belgium, France, Bosnia and Herzegovina, Portugal and Spain, and in Africa in Burundi, Djibouti, Liberia and Rwanda. The percentages range from 40 per cent in Costa Rica to 10 per cent in Djibouti. The laws in Belgium and Spain are phrased in a gender-neutral way, stating that a party list should not comprise more than 60 per cent of candidates of either sex. This strategy is useful for countering arguments that quotas are discriminatory; as they apply to both sexes, they cannot be said to discriminate. 
In addition to legislated quotas, voluntary party quotas are being frequently used. There are political parties in a further 30 countries that have voluntarily adopted, on a voluntary basis, their own policy of quotas for women. The party sets its own target or percentage of candidates they consider should be female. As the quota is voluntary however, there is no guarantee the party will meet its target.

\section{Implementing quotas}

How effective are quotas in practice? One striking fact of the past decade has been the increase in the number of parliaments with a 'critical mass' of women. By 2010, the number of chambers that have reached the 30 per cent target stands at 44 (26 single/lower and 18 upper houses), or 16.7 per cent of the total. This represents a six-fold increase over the seven chambers that had reached the target in 1995. In addition, there are several countries that are at the cusp of 30 per cent. Eleven chambers have also surpassed 40 per cent women members.

As shown in Table 2, 20 of the top-ranked 26 parliaments use electoral quotas or reserved seats. In seven of these countries, one or more political party, usually the ruling party, has adopted a voluntary party quota setting a percentage of the number of women candidates it fields for election. Another ten countries have legislated candidate quotas, specifying that between 30 and 40 per cent of candidates for election should be women. An additional three countries have reserved between 30 and 33 per cent of the seats in parliament for women. While quotas are not the only explanation for the high number of women in parliament, they do play a significant role.

During 2009, parliamentary renewals or elections took place in nearly 50 countries. Electoral quotas were used in several countries to improve the rate of participation of women. It is telling that in those countries that implemented quotas, women took

27 per cent of seats on average, as opposed to 13.8 per cent for those countries that did not use special measures. There are, however, a number of factors that need to work together for the successful implementation of quotas. In some instances, quotas are put in place but not enforced in practice.

\subsection{Enforcement}

A key criterion for the effective use of quotas is implementation and enforcement. Legislated candidate quotas are more effective when they carry with them sanctions for non-compliance. Here, it is useful to distinguish between indicative quotas and mandatory quotas. With an indicative quota, a target is set but may not be enforced, either because the law does not stipulate how to reach a target, or because political parties ignore it in the absence of enforcement mechanisms. This is the case in, e.g. Brazil previously, where although the law on quotas required political parties to present 30 per cent female candidates on its lists, there were no strict sanctions in place.

On the other hand, a compulsory quota not only sets a target, but also stipulates how it will be implemented, usually through a placement mandate or double quota. The law or regulations introduce measures so that women are placed in 'winnable' positions on party lists, i.e. every second or third place on the list, and the party electoral lists are rejected by the electoral authorities until they comply with the law. In Costa Rica, for example, strict enforcement measures oblige political parties to have at least 30 per cent women in winnable positions on candidate lists, failing which they will be unable to register the lists for the election. In Argentina, Mexico and Peru the original quota laws had to be amended because they were indicative and did not ensure compliance. Today, there are enforcement mechanisms in place.

\subsection{Electoral systems}

A further criterion is that the type of quota must match and work best with the electoral system in a country. Implementing a party candidate quota in a majority electoral system is not likely to have a huge impact. However, a proportional representation electoral system, with closed party lists, is likely to be the most favourable for implementing a quota for women. In addition, electoral systems that encourage high party fragmentation, or the election of several parties to parliament, have been more harmful to women's chances of election. Typically, women are placed further down on a list and therefore not likely to be elected if the party does not win several seats.

\subsection{Non-institutional factors}

The greatest successes with quota implementation have been registered when a variety of factors work in harmony. Political will 


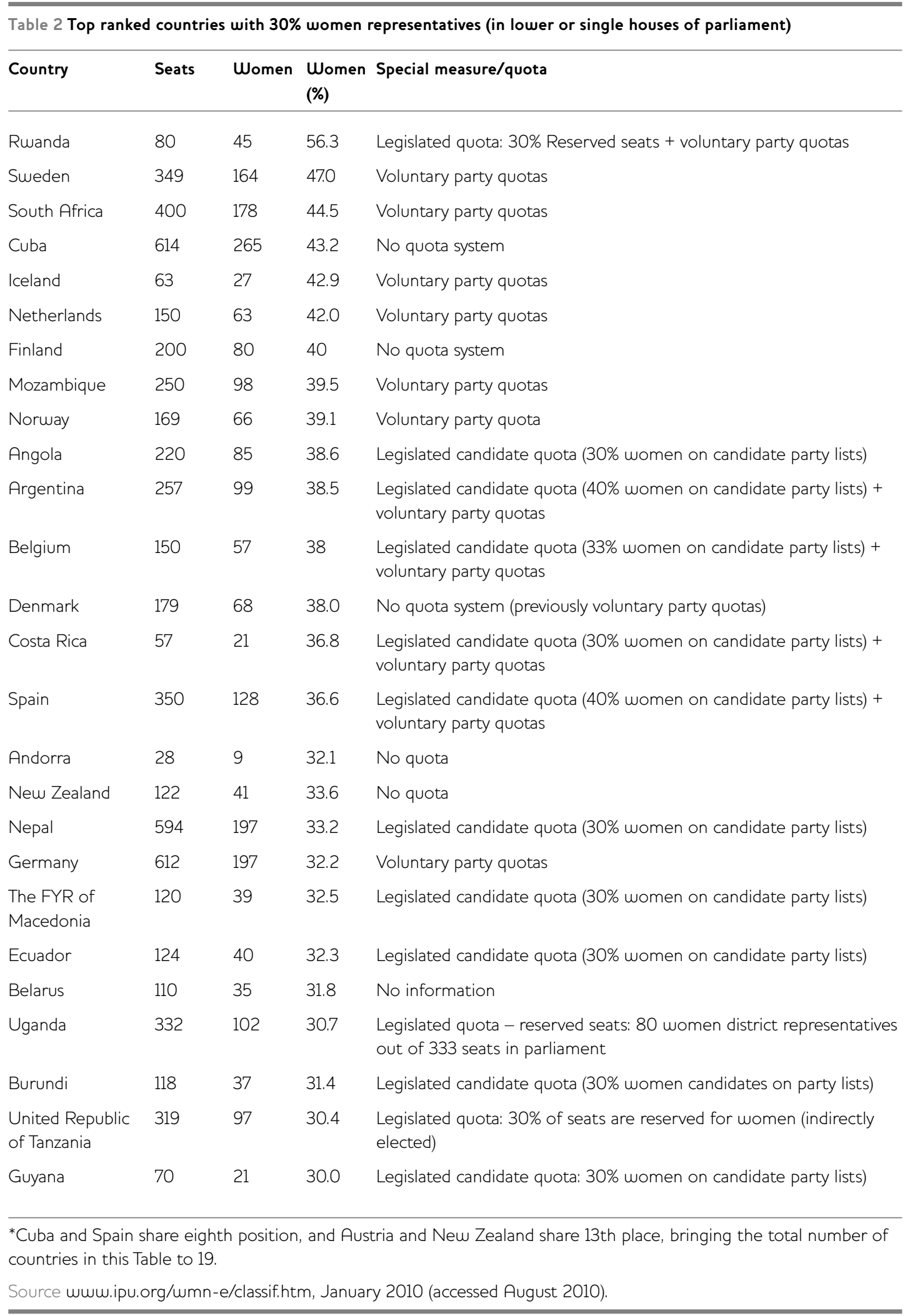


by leaders, sustained pressure by women's organisations and the continued emphasis placed on achieving gender equality by the international community are important factors. Support of political parties is important, as they need to ensure that they comply with the quota law, and if necessary, change internal party rules so that they work with the provisions of the quota laws.

Lastly, timing is crucial. In countries undergoing transition or constitutional and legal reform, there is a small window of opportunity for the introduction of quota laws. Ideally, such political reform should include the perspectives of all components of society, including women. It is much harder to amend the constitution and rewrite electoral laws or laws governing political parties in established regimes. The current debates on electoral reform in Brazil provide an ideal opportunity for the revision of the law on quotas.

\section{Conclusion}

The slow change in numbers over the past decades clearly demonstrates that women continue to face challenges relating to their political participation. However, the increase in the number of women in decision-making bodies is in large part attributable to institutional and electoral engineering, such as the adoption of electoral quotas and reserved seats.

\section{Notes}

* This article was originally prepared by Julie Ballington for the IPU submission to the Conference on International Experiences of Special Measures and the Difference Pathways to the Empowerment of Women in Politics in Brazil, in June 2007, and was updated in 2010.

\section{Further reading}

All websites accessed August 2010.

Inter-Parliamentary Union (2010) Women in Parliament in 2009: The Year in Perspective, Geneva: IPU, www.ipu.org

Inter-Parliamentary Union (2010) Women in National Parliaments, Geneva: IPU, www.ipu.org/wmn-e/world.htm

Inter-Parliamentary Union (2009) Women in Parliament: The Year in Perspective (2008), Geneva www.ipu.org/pdf/publications/wmn06-e.pdf
Quotas are not the only mechanism, however, to address the under-representation of women in politics and increase their access to political power. In practice, experience has shown that quotas must be supplemented with other measures, which range from awareness-raising to the training of women and the development of gender-sensitive environments. In addition, women may not have the necessary financial resources required to contest an election, and providing support in this regard is important. As political parties and political movements play an ever increasing role in the management of parliamentary politics, it is at the party level that the principle of equality must be put into practice. Political parties remain the gatekeepers to the advancement of women in politics.

Finally, international, regional and local organisations have also played their part. They have supported actors on the ground through the provision of information and tools for reform, by working directly with political parties, by providing training to women candidates seeking election or those already in parliament and through technical assistance projects. Promoting women's participation within international organisations is also a key factor.

1 See Inter-Parliamentary Union (2010) Women in Parliament in 2009: The Year in Perspective, www.ipu.org, compiled by this author.

Inter-Parliamentary Union (2005) Women in Politics 2005, poster, Geneva: IPU, www.ipu.org/english/surveys.htm\#45-05

International IDEA, Inter-Parliamentary Union and Stockholm University (2010) Global Database of Electoral Quotas for Women, www.quotaproject.org 